\title{
Domestic legislation and international human rights standards: the case of mental health and incapacity
}

\author{
Jill Stavert, Rebecca McGregor
}

Business School, Edinburgh Napier University, Edinburgh, Scotland

Correspondence details: j.stavert@napier.ac.uk and r.mcgregor@naiper.ac.uk

Jill Stavert is Professor of Law at Edinburgh Napier University and Director of the Centre for Mental Health and Incapacity Law, Rights and Policy.

Rebecca McGregor is a Research Assistant with the Centre for Mental Health and Incapacity Law, Rights and Policy, Edinburgh Napier University. 


\title{
Domestic legislation and international human rights standards: the case of mental health and incapacity
}

\author{
The right to health has been somewhat neglected in discussions about human \\ rights at both the national and international levels. States are often reluctant to \\ implement socio-economic rights which they consider to be a resourcing issue, \\ rather than a matter of rights. The right to mental health has received even less \\ attention and is rarely mentioned in national laws and policies, with the focus \\ remaining largely on compulsory care and treatment. The adoption of the United \\ Nations Convention on the Rights of Persons with Disabilities (CRPD) therefore \\ provides new impetus to explore the right to health, and mental health in \\ particular, for people with mental disabilities. By considering the rights to health \\ in Article 25 and to rehabilitation and habilitation in Article 26, together with the \\ right to exercise legal capacity under Article 12 CRPD and the support paradigm \\ inherent in this, it may be possible to achieve realisation of the right to mental \\ health in its broadest sense.
}

This article explores the links between Article 12, the support paradigm and the right to mental health. It also reflects on the existing legislative and human rights framework within Scotland and explores to what extent the right to mental health is currently being realised. It suggests that fully embracing the rights identified in Articles 12, 25 and 26 CRPD is required to achieve a shift in focus away from inappropriate compulsion and towards providing resources and services to support good mental health which could enable the realisation of the right to mental health at the national level.

Keywords: mental health; human rights; right to mental health; legal capacity

\section{Introduction}

It is now accepted that international human rights instruments are of little value without effective implementation. ${ }^{1}$ Such instruments may identify human rights and direct their rigorous implementation but ensuring that this is an actuality for those who these rights are supposed to protect and benefit is an entirely different matter. National laws, policies and practices that recognise such rights and allow for them to be given real 
effect are thus of primary importance. ${ }^{2}$ However, the very nature of such rights, the national priority given to them and how they are interpreted can both ensure and hinder their effective implementation. This can create tensions that impact on the extent to which rights can actually support human flourishing.

If we interpret, for instance, 'mental health’ in its widest sense of not simply encompassing mental illness or disease ${ }^{3}$ then it is crucial that these tensions are resolved. Achieving this requires that a state not only ensures the provision of adequate support and safeguards for those with mental disorder ${ }^{4}$ but also puts in place a framework which, at best, prevents its occurrence and, at the very least, minimises the impact of mental disorder on those who suffer from it. It requires an appreciation of the social, cultural, economic, political and environmental factors that impact on mental health and its attainment, and the need for accompanying enforceable relevant rights. ${ }^{5}$

There are two main obstacles to the attainment of the highest standard of mental health. Firstly, a medical model approach has traditionally been adopted towards persons with mental disorder who have been viewed, however benevolently, as being in need of supervision and control. This has been very much reflected in national laws and policies which have placed an emphasis on the concept of actual and potential risk of those with mental disorder to themselves and towards others and consequently sought to restrict rather than enable those who fall within their remit. Until the adoption of the United Nations (UN) Convention on the Rights of Persons with Disabilities (CRPD) in 2006, relevant international human rights standards also appeared to unquestioningly accept such interventions as inevitable and merely developed to define their limits. ${ }^{6}$ Secondly, the rights associated with defining such limits have tended to be civil rights. However, realising the right to the highest attainable standard of mental health and those rights which arguably support the achievement of this include social and 
economic rights and these generally require states to allocate resources which states are often reluctant to do at the best of times and especially in times of austerity.

In Scotland, the Scottish Human Rights Commission Getting it right? Human Rights in Scotland report noted that in terms of law 'references to human rights were frequent and explicit in the Scottish context. ${ }^{7}$ However, it was also stated that effective implementation of human rights standards requires that '[s]trong rights based legal and policy frameworks must be translated into more consistent positive outcomes to which individuals are entitled. ${ }^{, 8}$ In the context of mental health and incapacity, the process of promulgating rights-based mental health and capacity laws and policies, translating them into practice and delivering positive outcomes has encountered both successes and failures. A particular shortcoming being that references to the right to mental health and attempts to fully realise this right have been largely absent in legislative and policy discourse.

Taking these challenges into account, this paper will consider the development of the right to mental health under international law and the extent to which realisation of this is possible in Scotland. It will also discuss how the supported decision-making paradigm envisaged by Article 12 of the CRPD (the right to equal recognition before the law) can arguably be used to at the very least reduce impediments to the realisation of the right to mental health.

\section{The development of international human rights standards and mental health}

In comparison with developments of human rights standards in other areas over the last 60 years, the development of human rights standards relating to persons with mental disorder has been relatively slow. As Gostin and Gable reflected in 2004: 'The existing treaties and standards related to mental disability form an inconsistent patchwork of legal protections for persons with mental disabilities. ${ }^{9}$ 
Whilst the rights of those with mental disorder have progressively been acknowledged, such developments, until recently, merely reinforced a paternalistic medical model of disability and their consequent exclusion from society with a focus on treatment and protection. ${ }^{10}$ This was reflected in the 1971 UN Declaration on the Rights of Mentally Retarded Persons ${ }^{11}$ and again, twenty years later in the 1991 UN Principles for the Protection of Persons with Mental Illness (the MI Principles) which did little to improve the lives of persons with mental disorder. ${ }^{12}$ Nor did such instruments have the force of being binding under international law or provide any remedies in the form of independent monitoring, inspection or supervision. ${ }^{13}$

The position at European level has been similar insofar as the European Convention on Human Rights (ECHR) is concerned. Since its first 'mental health' case in $1979^{14}$, and in subsequent cases, the European Court of Human Rights has developed guidance as to when detention and involuntary treatment is justified, ${ }^{15}$ the conditions of detention, ${ }^{16}$ when such treatment amounts to inhuman and degrading treatment ${ }^{17}$ and when it is appropriate to limit or deny a person's ability to exercise and give effect to their choice/to exercise their legal capacity. ${ }^{18}$ However, the court's jurisprudence has been largely confined to institutional and treatment settings.

\section{Acknowledging a right to mental health}

In contrast to the aforementioned UN treaties and ECHR with their focus on detention and limiting state interference, various socio-economic human rights treaties including the European Social Charter and the International Covenant on Economic, Social and Cultural Rights (ICESCR) require states to take positive steps towards realising and promoting the rights they identify all of which are important for human development and flourishing. In particular, and essential to such development and flourishing is Article 12 of the ICESCR which identifies the right to health and defines it as: '... the 
right of everyone to the enjoyment of the highest attainable standard of physical and mental health.' It has been interpreted by the UN Committee on Economic, Social and Cultural Rights in its General Comment 14 as not a 'right to be healthy’ but rather as a right that constitutes both freedoms and entitlements. ${ }^{19}$ The entitlements conception is connected to the 'underlying determinants of health' which are defined as 'a wide range of socio-economic factors that promote conditions in which people can lead a healthy life ${ }^{20}$ including 'access to safe and portable water and adequate sanitation, an adequate supply of safe food, nutrition and housing, healthy occupational and environmental conditions, and access to health-related education and information..., ${ }^{21}$

However, despite being deeply embedded in the human rights framework, 'historic neglect of the right to health' ${ }^{22}$ means that the content of the right is not well established or widely discussed in policy making or academic literature. The right to the highest attainable standard of mental health has received even less attention and has been described as 'among the most grossly neglected elements of the right to health.' ${ }^{23}$ However, acknowledging the importance of mental health, the former UN Special Rapporteur on Health, Paul Hunt, stated that:

'...the right to mental health is not simply a concern of persons with mental disabilities, but also the population more generally. Mental health is a central element of good health and the right to mental health is a central element of the right to health for all. ${ }^{24}$

This succinctly locates the right to mental health within the right to health, as interpreted by the UN Committee on Economic, Social and Cultural Rights, and as the sum of the freedoms and entitlements that are necessary to secure such right. It therefore opens up the possibility of claiming mental health services and goods as basic entitlements, extending it beyond access to the care and treatment of persons with 
mental disorder and encompassing access to services and support intended to improve mental health and to protect and maintain good mental health. As Hunt states:

\begin{abstract}
'States should take steps to ensure a full package of community-based mental health care and support services conducive to health, dignity, and inclusion, including medication, psychotherapy, ambulatory services, hospital care for acute admissions, residential facilities, rehabilitation for persons with psychiatric disabilities, programmes to maximise the independence and skills of persons with intellectual disabilities, supported housing and employment, income support, inclusive and appropriate education for children with intellectual disabilities, and respite care for families looking after a person with mental disability 24 hours a day. ${ }^{25}$ (Emphasis added)
\end{abstract}

These examples of the types of goods and services which contribute to securing the right to mental health demonstrates the need for states to develop holistic policies which are aimed at providing inclusive services for people within their own community.

The view that the concept of 'mental health' must be seen as being broader than simply mental illness has also been reinforced by the current UN Special Rapporteur for Health, Dainius Pūras. ${ }^{26}$ In emphasising the centrality of the right to mental health to the right to health ${ }^{27}$ he has noted that the realisation of the right to mental health has been hampered by the failure of states to recognise this and the consequent low priority afforded to mental health relative to physical health. ${ }^{28}$

\title{
Scottish mental health and incapacity legislation
}

Whilst the right to health thus provides a foundation upon which to strengthen access to services for persons with mental disabilities there has been limited use of the right to health in the mental health field and national law and policy, with legislation on involuntary treatment generally favouring compulsion over securing the provision of access to treatment informed by principles of support, choice and autonomy. ${ }^{29}$ For instance, Scotland's mental health and incapacity laws are regarded as good examples 
of principled and human rights based legislation providing a framework for robust protection of civil rights by minimising the circumstances under which an individual can be compulsorily detained and treated or placed under guardianship. During the drafting of both the Mental Health (Care and Treatment) (Scotland) Act 2003 (the 2003 Act) and the Adults with Incapacity (Scotland) Act 2000 (the 2000 Act), there was a commitment to the upholding and protection of human rights and an awareness that any compulsory interventions in an adult's life must be minimal. ${ }^{30}$ In line with this, both the 2000 and the 2003 Acts are underpinned by principles which must be applied when carrying out functions under the legislation. In particular, principles requiring 'minimum restriction on the freedom of the patient' ${ }^{31}$ and 'least restrictive option' 32 are intended to secure liberty and avoid compulsion. The 2003 Act has even been described as ' ...the most civil rights oriented laws of all the mental health laws in Western Europe. ${ }^{33}$ The Scottish Human Rights Commission's Getting it right? report also noted that the 2003 Act and the 2000 Act were both viewed as forward-thinking and advanced pieces of legislation which did effect culture change amongst mental health professionals. $^{34}$

Other principles in the 2000 and 2003 Acts further require that those operating within the framework provide maximum benefit to the individual and take account of their past and present wishes and feelings, as well as the views of their relatives, guardian or other person(s) with an interest in the individual's welfare. ${ }^{35}$ The 2000 Act also requires that anyone exercising functions under the Act 'encourage the adult to exercise whatever skills he has concerning his property, financial affairs or personal welfare, as the case may be, and to develop new such skills. ${ }^{36}$ In contrast to the principles regarding least restriction, these principles promote a more holistic approach to the operation of the legislation. They are a reminder that individuals who are 
impacted by this law should, fundamentally, be participants in their care and treatment, that they have a right to be heard and that there is always scope for developing and promoting their capacity.

Research has, however, shown a lack of awareness and application of the principles of the legislation amongst health care staff ${ }^{37}$ and the use of restraint and seclusion for individuals in care homes or psychiatric hospitals has been noted as problematic in terms of interfering with physical and mental integrity. ${ }^{38}$ The Mental Welfare Commission has also highlighted issues with variable compliance with consent to medication requirements ${ }^{39}$ such consent being integral not only in terms of protecting individuals from interferences with their bodily integrity, but also in terms of enabling them to exercise their capacity and secure their right to health through making informed choices about healthcare. Moreover, both the 2000 and 2003 Acts do not explicitly provide for a right to health. These issues signal the need for a greater engagement with human rights in general and the right to mental health in particular in order to more fully achieve positive outcomes. In this regard, the rights to exercise legal capacity, to health and to rehabilitation and habilitation identified, respectively, in Articles 12, 25 and 26 CRPD if realised in parallel potentially arguably provide an opportunity to revisit this and to realise the right to mental health in its widest sense.

\section{United Nations Convention on the Rights of Persons with Disabilities: Advancing the right to mental health}

The CRPD ${ }^{40}$ did not introduce any new rights but it aligns and brings together equality and civil, political and socio-economic rights in a way that is meaningful for persons with disabilities. It recognises that existing law and human rights paradigms were not working for persons with disabilities, including those with mental disorder ${ }^{41}$, and in promoting a social, as opposed to a medical, model of disability it makes it clear that it 
is society that disables rather than the disability itself. ${ }^{42}$ For instance, in stating that it applies to all persons ' .... who have long-term physical, mental, intellectual and sensory impairments..' the CRPD identifies these impairments as resulting from '...interaction with various barriers [that] may hinder their full and effective participation in society on an equal basis with others. ${ }^{43}$

The CRPD also introduced unique monitoring mechanisms in response to calls from numerous states and organisations (particularly disabled people’s organisations) which sought to strengthen the mechanisms for monitoring human rights implementation. ${ }^{44}$ In Article 33 there is accordingly an attempt to address the perceived ineffectiveness of other human rights treaty monitoring systems by providing strong innovative mechanisms which attempt to avoid the difficulties encountered with other instruments ${ }^{45}$ and which have been described as 'arguably the most complete provision on national level implementation and monitoring ever in an international human rights treaty and represents one of the most innovative provisions in the Convention.' ${ }^{46}$ It seeks, for example, to promote 'holistic disability policies' ${ }^{47}$ and attempts to integrate the CRPD into all areas of governance by placing an obligation on states parties to specifically charge an element or elements within government to ensure CRPD implementation and to '...give due consideration to the establishment or designation of a coordination mechanism within government to facilitate related action in different sectors and at different levels. ${ }^{48}$

Article 33 also requires states parties to ensure independent oversight of the implementation of the Convention ${ }^{49}$ in that they must designate or establish mechanisms which are consistent with the Principles relating to the Status of National Institutions for Protection and Promotion of Human Rights (the Paris Principles). ${ }^{50}$ This therefore envisages that national human rights institutions will be actively involved 
in the monitoring of compliance with the CRPD. There is also a requirement for the involvement and participation of civil society in the monitoring process ${ }^{51}$ allowing for people with disabilities to be represented in all aspects of Convention co-ordination and monitoring. ${ }^{52}$

In terms of substantive provisions, while the CRPD does not contain any new rights, it restates existing human rights expanding upon how they should be interpreted and applied for persons with disabilities. As such, in common with Article 12 ICESCR, Article 25 CRPD recognises the 'right to the enjoyment of the highest attainable standard of health...' However, it significantly expands on this in the context of disability by requiring, inter alia, that persons with disabilities are provided with the same range, quality and standard of health care and programmes as provided to other people $^{53}$ and, in addition, that persons with disabilities are provided with health services they require because of their disability and services to minimise and prevent further disabilities. ${ }^{54}$ States are also obliged to require health professionals to provide care of the same quality to persons with disabilities on the basis of free and informed consent by raising awareness of the human rights, dignity, autonomy and needs of persons with disabilities through training and the promulgation of ethical standards for public and private health care. ${ }^{55}$

The positive obligation on states to provide services specifically related to the person's disability considerably opens up the right to health for people with mental disorder and includes the provision of services to prevent mental disability and to minimise the impact of such disability. Moreover, considered in combination with states' positive obligation to give effect to the right to habilitation and rehabilitation identified in Article 26 CRPD, the right to mental health, interpreted widely, can be understood as including not only rights in connection with care and treatment, but also 
in terms of access to relevant support and services and providing these in an environment which assists in maximising health and wellbeing. For example, Article 26(1) provides that:

\footnotetext{
'States parties shall take effective and appropriate measures, including through peer support, to enable persons with disabilities to attain and maintain maximum independence, full physical, mental, social and vocational ability, and full inclusion and participation in all aspects of life. To that end, States Parties shall organize, strengthen and extend comprehensive habilitation and rehabilitation services and programmes, particularly in the areas of health, employment, education and social services, in such a way that these services and programmes:

Begin at the earliest possible stage, and are based on the multidisciplinary assessment of individual needs and strengths;

Support participation and inclusion in the community and all aspects of society, are voluntary, and are available to persons with disabilities as close as possible to their own communities, including in rural areas.' [Emphasis added]
}

Moreover, the UN Committee on the Rights of Persons with Disabilities has highlighted the vital connection between the right to the highest attainable standard of health and all other human rights and to the exercise of full and effective participation in development and society. ${ }^{56}$

At this juncture, it is important to note that notwithstanding their potential the positive rights identified in Articles 25 and 26 CRPD are socio-economic rights. As previously mentioned, in the case of persons with mental disorder states have traditionally tended to focus on providing care and treatment within the context of the medical model of disability and the role of human rights has been predominantly confined to addressing interferences with civil rights to liberty, autonomy and freedom from inhuman and degrading treatment. ${ }^{57}$

It has however, been suggested that in the context of persons with mental disorder endorsing and advancing the relationship between the right to exercise legal 
capacity and the right to health potentially provides a way in which to more effectively and concomitantly realise these rights. ${ }^{58}$ Moreover, by harnessing the support for the exercise of legal capacity paradigm emphasised in Article 12 CRPD any impasse that might be created when civil and socio-economic rights confront each other in the field of mental health may arguably be resolved. 59

\section{Article 12 CRPD: the right to equal recognition before the law}

Article 12 is central to the contention that effective implementation of the right to mental health could bring benefits to people with mental disorder in terms of improved mental health and less need for compulsory measures. On the face of it, Article 12(2) is clear - 'persons with disabilities enjoy legal capacity on an equal basis with others in all aspects of life.' Article 12(3) goes on to elucidate how this right can be made effective for persons with disabilities by requiring states parties to 'take appropriate measures to provide access by persons with disabilities to the support they may require in exercising their legal capacity.' Thus far literature on the CRPD has been largely devoted to exploring Article 12, its interpretation and relevance for people with mental disorder. The UN Committee on the Rights of Persons with Disabilities has been pivotal in directing the course of the debate by stating in its General Comment No.1 that Article 12 is a universal right which requires that people with disabilities are never denied their right to legal capacity based on an assessment of their mental capacity. ${ }^{60}$ Rather, the Committee says that persons with disabilities should be provided with the support they require to exercise their legal capacity in a way that gives effect to their rights, will and preference. ${ }^{61}$

The universal interpretation of legal capacity pronounced by the Committee is potentially revolutionary for mental health and capacity laws around the world by requiring their abolition and replacement with regimes of supported decision-making. 
This has ignited a fervent debate across the globe about whether any degree of substitute decision-making is acceptable, and the extent to which people with severe and enduring mental disorders can be supported to make decisions. ${ }^{62}$

Individuals and organisations have viewed the universal right to legal capacity as the keystone to securing the protection of all human rights of persons with mental disabilities. Indeed, the right to capacity is fundamental for the exercise of many other rights, and its denial can have a significant adverse impact on the individual who is subject to such deprivation(s). Tina Minkowitz has highlighted the importance of Article 12:

'This guarantee is the heart of the Convention for people with psychosocial disabilities. All laws directed at restricting our freedom and self-determination are premised on an equation of psychosocial disability with legal incapacity, and legal incapacitation is the primary way that the law deals with persons with psychosocial disabilities. A guarantee of legal capacity on an equal basis with others in all aspects of life should result in the elimination of all such regimes. ${ }^{, 63}$

While the ending of substitute decision-making regimes is thus considered by some commentators as the ultimate way in which to restore equality for persons with mental disabilities, ${ }^{64}$ no states have completely moved to this paradigm. This article will not explore the intricacies of this debate, but instead suggests that the foundational principle of support for the exercise of legal capacity can be used to inform interpretation of other CRPD rights, including Articles 25 and 26.

The CRPD 'blends civil and political rights with economic, social and cultural rights' which has resulted in the distinction between rights subject to immediate realisation and rights subject to progressive realisation being 'effectively abandoned' ${ }^{65}$ This 'restating' of the relationship between civil and political and socio-economic rights should alter how these provisions are interpreted and implemented at national level and 
lead to a better understanding about the necessity of actively engaging with all human rights.

Realising the right identified in Article 12 can, therefore, reinforce those identified in Articles 25 and 26 CRPD and ensure that individuals are provided with the range of services and access to support, as may be required, to achieve the highest attainable standard of mental, and physical, health. Moreover, it is certainly arguable that if such services and support are provided then compulsory treatment will not be necessary for people with mental disorder. ${ }^{66}$ As Rosenthal and Rubenstein commented in 1993:

'Greater resources, better quality services and greater integration with other forms of health care and social services can make it possible to protect liberty. ${ }^{67}$

From this perspective, force and compulsion are seen as avoidable and the way of negating these issues appears simply to be by providing people with the services that they want and supporting them to access these. The individual is able to exercise their capacity in choosing services, while also securing their right to mental health. Of course, the extent to which support for the exercise of legal capacity or 'supported decision-making' can be employed for all persons with a mental disability or capacity issue in all situations, is far from clear. ${ }^{68}$ However, regardless of this debate, there is considerable traction in the argument that governments should provide services that people want and that the provision of support and choice in healthcare could have a significant impact on the need for compulsory measures. The CRPD provides the tools for doing this. 


\section{Realising the right to mental health in Scotland using the support for the exercise of legal capacity paradigm?}

The importance of the CRPD within Scotland should not be underestimated. Although its rights are not legally enforceable in the UK, devolved Scottish legislation and actions of the Scottish Ministers can be prevented by the UK government where they contravene the UK's international obligations, including those under international human rights treaties. ${ }^{69}$ Moreover, Scottish devolved legislation and policy that gives effect to CRPD rights is imperative if the right to mental health is to be fully realised. It is therefore essential that Scotland revisits its mental health and incapacity laws in order to assess its compliance with the CRPD and determine how it can more effectively translate and implement its provisions. ${ }^{70}$

While Scottish legislation is primarily concerned with compulsory measures and does not provide for a right to health as such, the 2003 Act does place limited duties on local authorities and/or health boards to provide stipulated services and both pieces of legislation also enable individuals to make use of advance planning mechanisms wherein they can specify their treatment preferences. Taken together with the principles, the legislation attempts to imbue some degree of reciprocity where the individual (while possibly also being subject to compulsion) is provided with support and services to secure their right to mental health/the highest attainable standard of mental health, either prior to or concurrent with, compulsory measures.

While it must be acknowledged that legislation and policies alone do not lead to the development of new services, they represent a fundamental part of the wider framework required to secure the right to mental health. ${ }^{71}$ As stated by Hunt:

\footnotetext{
'...the right to health must be integrated into national and international policy making processes. In this way, the right to health can shape laws, policies, programmes and projects. ${ }^{72}$
} 
As such, the following sections will thus briefly examine some of the Scottish legislative provisions which could promote the right to mental health and, in light of the above comments on Articles 12, 25 and 26 CRPD, make suggestions for amendments and/or policies which could secure greater integration of the right to mental health and positive outcomes for individuals.

\section{Advance Planning}

Advance planning has been referred to by the Committee on the Rights of Persons with Disabilities as 'an important form of support' which allows individuals to 'state their will and preferences which should be followed at a time when they may not be in a position to communicate their wishes to others. ${ }^{, 73}$ The importance of developing and promoting such forms of support should therefore be at the forefront of efforts to develop a more CRPD-compliant mental health system.

In Scotland advance planning mechanisms are acknowledged and regulated through provision for the making of powers of attorney under the 2000 Act and psychiatric advance statements under the 2003 Act. It could be argued that these forms of advance planning, as they largely ${ }^{74}$ become operational upon incapacity, are noncompliant with Article 12 CRPD as interpreted by the Committee on the Rights of Persons with Disabilities in its General Comment No. $1 .^{75}$ However, there is nevertheless a compelling argument that insofar as they operate to give effect to the exercise of a person's legal capacity, even where a person is unable to personally exercise that capacity, then the requirements of Article 12 CRPD are in fact met. ${ }^{76}$

Powers of attorney can be made in relation to an individual's financial and/or welfare affairs and enables individuals, with the requisite capacity and subject to certain conditions, ${ }^{77}$ to put in place arrangements for the management of their financial and/or welfare affairs by appointing an attorney to act on their behalf. The making of a power 
of attorney is intended to allow individuals to plan for potential future incapacity and to set out in as much detail as they choose how their affairs should be managed. The granting of a power should be a participatory process whereby the granter is fully involved in communicating their wishes and feelings to their attorney. ${ }^{78}$ There is almost no restriction on who can be appointed as an attorney, or on the types or extent of powers that can be conferred, indicating that the main purpose of this mechanism is to advance the granter's autonomy at a time when they are either unable or unwilling to make their own decisions. ${ }^{79}$

Under the 2003 Act people have the right to make an advance statement wherein they can stipulate the ways they wish and do not wish to be treated for mental disorder in the event that they become mentally disordered and their ability to make decisions becomes significantly impaired. ${ }^{80}$ Atkinson notes that when advance statements were first introduced, it was clear that they were to be used to cover clinical treatment, 'but not wider aspects of management or stay in hospital. ${ }^{81}$ However, research from 2010 showed that the majority of advance statements contained both information in relation to the individual's treatment preferences as well as wider issues, ${ }^{82}$ perhaps demonstrating the difficulties that people encounter in attempting to separate decisions or preferences in relation to medical treatment from other issues which they consider to be just as important to their mental health, such as for example having access to friends and family.

However, the main issue with advances statements is that the legislation only requires that the Mental Health Tribunal for Scotland and any person giving medical treatment under the Act 'have regard' to its contents and are not obliged to follow its provisions. ${ }^{83}$ This may be the reason that there has been a low uptake of advance statements. Indeed, in the 2009 McManus Review of the 2003 Act it was noted that 
because advance statements can ultimately be overridden, there is a widespread belief that no regard will be given to the statement. ${ }^{84}$

That being said, outside Scotland, studies have reported that the making of advance statements, or advance directives as they are alternatively known, has numerous therapeutic benefits including empowering the individual, enhancing capacity, improving the patient/clinician relationship and, most significantly, reducing the need for involuntary detention. ${ }^{85}$ These benefits align with previous comments about the value of participatory care and services for extending and improving mental health. With the potential benefits of advance statements appearing not to have been fully realised in Scotland, recent amendments to the 2003 Act (effected by the Mental Health (Scotland) Act 2015) aim to address some of the problems. When they come into force the new provisions will require health boards to place a copy of a patient's statement in their records and inform the Mental Welfare Commission that a copy of the statement is held with the person's medical records and where the records are kept. ${ }^{86}$ The Commission is also obliged to maintain a register of advance statements ${ }^{87}$ and is charged with monitoring the obligation on health boards to publicise any support they offer for the making or withdrawing of advance statements. ${ }^{88}$ While these amendments ought to assist in ensuring that advance statements are taken into account in care and treatment situations and in monitoring their use, greater consideration must be given to ensuring that they are a support mechanism which truly enables individuals to proactively secure and improve their mental health. 


\section{Services - Advocacy and Sections 25-27 Mental Health (Care and Treatment) (Scotland) Act 2003}

\section{Independent Advocacy}

Another means by which Scottish legislation identifies the requirement for choice and support in health care and social services is through the provision of independent advocacy services. Under the 2003 Act all individuals who have a mental disorder (regardless of whether they have been subjected to compulsory measures under the Act) have the right to access independent advocacy. ${ }^{89}$ The Act places a duty on local authorities and health boards to secure its availability and to ensure people have the opportunity to use the services.

'Advocacy services' are defined in the legislation as:

'...services of support and representation made available for the purpose of enabling the person to whom they are available to have as much control of, or capacity to influence, that person's care and welfare as is, in the circumstances, appropriate. ${ }^{90}$

The Scottish Independent Advocacy Alliance states that a main principle of independent advocacy is that services should be directed by the individual concerned and should assist the person in exercising control over their life. ${ }^{91}$ As such, independent advocacy is regarded as a crucial tool for many people with mental disabilities, helping them to understand and access their rights ${ }^{92}$ and supporting greater choice and control for people who use services. ${ }^{93}$

During the drafting of the amending legislation in 2015, there were calls from various organisations for the strengthening of provisions relating to independent advocacy in the 2003 Act. Whilst the 2015 Act did not go as far as many would have wished in this respect, it has introduced a new provision which requires health boards 
and local authorities, when requested, to provide information to the Mental Welfare Commission about how they are exercising, and how they intend to exercise, their functions in relation to independent advocacy. ${ }^{94}$ Whether this will have any real effect on improving the availability and quality of advocacy services remains to be seen.

Independent advocacy has the potential to be one of the most effective mechanisms available in Scotland which can help individuals to work towards achieving the highest attainable standard of mental health. It certainly appears to be a vital support mechanism for achieving compliance with Article 12(3) of the CRPD, ${ }^{95}$ given that it is not influenced by capacity assessments and is entirely based on determining and giving effect to the individual's will and preference, the interpretation of Article 12 advanced by the Committee on the Rights of Persons with Disabilities. However, the lack of substantial amendment to the advocacy provisions under the 2003 Act could, as forewarned by the Scottish Independent Advocacy Alliance, negatively impact the availability of services that promote the highest attainable standard of mental health. ${ }^{96}$ It is therefore imperative that legislation clearly sets out the role of independent advocates and the principles by which they should operate and also that independent advocacy is funded at an appropriate level. ${ }^{97}$

\section{Sections 25-27}

Sections 25-27 of 2003 Act also provide additional rights to persons who have or have had a mental disorder to access care and support services; services designed to promote well-being and social development; and assistance with travel to participate in these services.

Thus, the potential certainly exists for these provisions to give access to the kinds of services and support envisaged for CRPD compliance in terms of addressing, minimising and preventing mental illness, and promoting mental health. This will, 
however, necessitate adequate resourcing and monitoring and the Scottish Government has recently noted concern that some local authorities may be failing to fully carry out their duties contained within sections 25-27. ${ }^{98}$ Similarly, the Mental Welfare Commission has highlighted a lack of recognition amongst local authorities about their duties under these provisions. ${ }^{99}$ A significant contributory factor here is no doubt the absence of clarity in the legislation and its codes of practice as to which national agency is actually responsible for overseeing implementation of these provisions and an absence of independent monitoring. Thus, given the lack of comprehensive assessment of compliance with sections 25-27, whilst there may be some examples of good practice around the country, it is impossible to properly ascertain the extent to which sections 25-27 support is provided across Scotland. Stronger commitment to providing greater legislative direction as to who actually provides sections 25-27 services and monitors the adequacy of their provision, and to their resourcing, is thus required. It is also imperative that any monitoring that takes place to assess the adequacy of these services involves individuals who have lived experience of accessing, or trying to access, such services. This will enable a more accurate reflection of what is happening 'on the ground' and is in line with the participation principle which underpins the CRPD.

\section{Scottish legislation - Future developments}

The foregoing sections have illustrated means by which Scotland is providing individuals with support and services that can be used, or developed, to realise their right to mental health. However, as previously mentioned, where this involves the effectiveness of realisation of socio-economic rights this is greatly influenced by resourcing levels. For example, the Scottish Human Rights Commission noted that the programme of austerity pursued by the UK Government since 2010 'has had consequential impacts on the availability of resources for the realisation of human rights 
in Scotland. ${ }^{100}$ In particular, and closely connected to the right to health, is the impact such austerity has had on pursuing the right to independent living. The UK Government, for example, abolished the Independent Living Fund in 2015 which had been used to support people to live independently by providing additional funding to address high support needs although, encouragingly, the Scottish Government committed to continuing to provide additional funding to support independent living. ${ }^{101}$ However, whilst the Scottish Independent Advocacy Alliance’s 2013-2104 Advocacy Map found that demand for advocacy in Scotland had increased by 8\% on the previous year it also found that funding for these services had either been reduced or frozen. ${ }^{102}$ In its 2016 Concluding Observations for the UK, the Committee on Economic, Social and Cultural Rights stated that it was ' ....seriously concerned about the disproportionate, adverse impact that austerity measures introduced in 2010 area having on the enjoyment of economic, social and cultural rights by disadvantaged and marginalised individuals and groups... ${ }^{103}$ and specifically includes persons with disabilities within its definition of such individuals and groups. ${ }^{104}$

That being said, whilst adequacy of funding is an important consideration in the realisation of the right to mental health recent research has also suggested that potential amendments to legislation could be made to contribute to the adoption of a more CRPD-compliant approach. ${ }^{105}$ This could involve, for example, the inclusion in the 2000 and 2003 Acts of a rebuttable presumption that effect will be given to the will and preferences of the individual thus providing a greater degree of protection for legal capacity with the resultant avoidance or delay in the need for compulsory measures. ${ }^{106}$ In tandem with this, including a requirement within legislation to show that all available support has been provided to a person before compulsory measures can be taken, 
provides the individual with real opportunities to access health and social care services without immediate compulsion.

The value of advance planning should also not be underestimated for enabling individuals to direct the course of their care and treatment at times when they become unwell or are unable or unwilling to exercise their capacity. Advance planning can be used to both support individuals to exercise their capacity for specific decisions, perhaps with the assistance of an independent advocate. As previously indicated, it can also be used to 'extend legal agency' in circumstances where a person is deemed to not have capacity. ${ }^{107}$ It is therefore imperative that Scotland strengthens its advance planning provisions by requiring a much greater engagement with such documents amongst all professionals, not just those working in health care. The services provided for under the 2003 Act also hold potential for harnessing participatory care for persons with mental disorder. However, in some respects Scottish legislation falls short, both in theory and in practice, of realising and securing these outcomes. As noted, legislation alone will not provide an entirely CRPD-compliant system but it is important that changes are made to ensure that the legal frameworks are as robust as possible to set the foundation for influencing policy and practice.

\section{Realising the CRPD in Scotland}

As previously noted, in addition to Scotland's obligations relating to health and support, the CRPD also obliges states to engage with it through its monitoring mechanisms. This is reflected within the UK by the Office for Disability Issues (part of the Department for Work and Pensions) being designated as the national coordination mechanism with responsibility for coordinating the implementation of the CRPD across government. There are also separate focal points in the devolved governments, such as the Scottish Government Equality Unit. ${ }^{108}$ This has prompted an engagement with the 
CRPD at national level which is possibly unparalleled with other international instruments. The Scottish Government has for instance published a Draft Delivery Plan for the CRPD which uses the CRPD as the framework to deliver change across all policy areas and services to secure positive outcomes for people with disabilities. ${ }^{109}$ Whilst specific reference to the right to mental health is absent in this, the consultation process arguably provides a forum for bringing the importance of this right to the attention of policy makers. It also emphasises the fact that international law has real meaning and authority for practice in Scotland.

In addition, the independent oversight of implementation of the Convention required by Article $33 \mathrm{CRPD}^{110}$ is being undertaken in Scotland by the Equality and Human Rights Commission and the Scottish Human Rights Commission (known collectively as the UK Independent Mechanism). The UK Independent Mechanism published its first report on CRPD implementation in 2014. In its assessment of Article 25 , the report noted that people with a mental health condition are more likely to experience health problems and inequalities and to die younger than other people. ${ }^{111}$ The report also highlighted the 'low levels of disability awareness among health care staff' and failure to deal with physical conditions if they are perceived to be a consequence of a mental health condition. ${ }^{112}$ Findings in Scotland pointed to 'unmet needs' in Intensive Psychiatric Care Units and 'a lack of activities, rehabilitation or a therapeutic environment; a 'one size fits all' approach to risk management and a lack of opportunities for meaningful involvement in the care process. ${ }^{, 13}$ The report also endorsed the recommendation from the 2010 Joint Committee on Human Rights report, Implementation of the Right of Disabled People to Independent Living, that 'the Government make a clear and unequivocal commitment to Parliament...that they will give due consideration to the articles in the UN Disabilities Convention when making 
new policy and legislation'. ${ }^{114}$ So far, no such commitment has been made by either the UK or Scottish governments.

While there is much work to be done in Scotland to more effectively realise the right to health and the CRPD more generally, the Scottish Government has firmly placed mental health on the political agenda. Whilst recently announcing that an extra $£ 54$ million was to be added to the mental health budget First Minister Nicola Sturgeon stated that: 'It is vital that the health service is properly equipped to give those who need support and treatment access to mental health services as early as possible. ${ }^{, 15}$ In addition to this, a review of the 2000 Act is currently underway ${ }^{116}$ and a new Scottish Government Mental Health Strategy is forthcoming ${ }^{117}$ with such developments being continuously informed and monitored through the involvement of disabled peoples’ organisations, statutory bodies and professionals. The Scottish Association for Mental Health (SAMH) for instance, recently published a research report showing that the Scottish Government has failed to reach its target of an 18 weeks waiting time for access to psychological therapies across all health boards. ${ }^{118}$ It calls on the Scottish Government to commission an independent inquiry into this failure and to implement a target of 12 weeks, which would give mental health treatment parity with targets for other illnesses.

It is not doubted that the Scottish Government is engaging with mental health and attempting to make progress in this area. However, time will tell whether this, together with the role played by independent organisations, disabled people and the UK Independent Mechanism, will achieve meaningful implementation of the rights identified in the CRPD by ensuring that they are integrated into law, policy making and public discourse and ultimately lead to securing the support and services required for the full realisation of the right to mental health. 


\section{Conclusion}

Seeking to achieve the realisation of the right to mental health in its widest sense requires an appreciation that mental health is more than simply mental disorder that can be dealt with by clinical and, sometimes, compulsory care and treatment. It requires a commitment to providing the necessary support and services, including support for the exercise of legal capacity. It requires addressing the lack of parity between respect for civil and socio-economic rights ${ }^{119}$ and between physical and mental health support and service provision. The CRPD may provide the tools to achieve this.

The right to health as provided for under Article 25 CRPD and understood in light of the CRPD's general principles and rights to capacity and habilitation, provides individuals with rights to access to a range of care, treatment and services in their own community and in an environment which maximises health and well-being and with support if required. This includes being able to make choices about the support and services that they receive and, where necessary, equality of access to justice in pursuing this. ${ }^{120}$ Concentrating on positive rights obligations under the CRPD may reinforce realisation of the right to health and mental health and provide the impetus for a fundamental shift in the way in which states approach both mental health and mental illness. $^{121}$

However, it is the translation of this at national level which is most problematic. Currently, the position in Scotland and across the UK does not fully reflect the requirements of the CRPD. Scottish legislation is largely focussed on the compulsory aspects of the care and treatment of people with mental disorder and while they do contain important provisions aimed at enabling individuals to participate in their health care, they do not always fully achieve this aim. Thus, despite 'frequent and explicit' references to human rights in Scottish law, the extent to which these include socio- 
economic rights and have become real and effective for individuals subject to such law is doubtful. It is therefore vital that all policies and innovations related to mental health take a human rights based approach, integrating 'the norms, standards and principles of the international human rights system into everyday policy and practice'. ${ }^{122}$ This includes the meaningful involvement of persons with lived experience of mental disorder in the formulation and implementation of relevant legislation and policies as is required by both the CRPD ${ }^{123}$ and the World Health Organisation Mental Health Action Plan 2013/2020. ${ }^{124}$

The CRPD and the monitoring mechanisms contained within it have provided new impetus to revisit the right to mental health and to ensure its integration into law and policy. Scotland appears to be beginning to engage with the challenges the CRPD has presented and although there remains much to be done, the Scottish Government has not avoided confronting issues surrounding mental health such as the need for parity and increased funding. Oversight of this by the UK Independent Mechanism, amongst others, provides increased optimism that the paradigm shift of the CRPD may be largely, if not fully, realised. It is imperative that Scotland seizes this opportunity to actively engage with the right to mental health at all levels and to operationalise it in a way which results in real and effective implementation not only for those with mental disorder, but for the population as a whole. 
${ }^{1}$ Elizabeth Mottorshaw and Rachel Murray, 'National Responses to Human Rights Judgments: The Need for Government Co-ordination and Implementation', European Human Rights Law Review 6 (2012): 639.

${ }^{2}$ Eric Rosenthal and Leonard S. Rubenstein, 'International Human Rights Advocacy under the 'Principles for the Protection of Persons with Mental Illness', International Journal of Law and Psychiatry 16 (1993): 288.

${ }^{3}$ Such an interpretation mirrors that of the World Health Organisation (WHO). See, for example, WHO, Mental Health: strengthening our response, Factsheet, updated April 2016, available at http://www.who.int/mediacentre/factsheets/fs220/en/ (accessed 10 June 2016) where it states 'Mental health is a state of well-being in which an individual realizes his or her own abilities, can cope with the normal stresses of life, can work productively and is able to make a contribution to his or her community.' See also WHO, Constitution and Mental Health Action Plan 2013/2020, paragraph 08, available at http://www.who.int/governance/eb/who_constitution_en.pdf and http://apps.who.int/iris/bitstream/10665/89966/1/9789241506021_eng.pdf?ua=1 (accessed 10 June 2016) which sees ‘mental health' as an integral and essential component of 'health'.

${ }^{4}$ For the purposes of this paper the definition of 'mental disorder' found in section 328 of the Mental Health (Care and Treatment)(Scotland) Act 2003 will be adopted in that it includes mental illness, learning disability and personality disorder.

${ }^{5}$ WHO, Constitution and Mental Health Action Plan 2013/2020, paragraphs 7 and 9-10.

${ }^{6}$ T.W Harding, 'Human Rights Law in the Field of Mental Health: A Critical Review', Acta Psychiatrica Scandinavica 101 (2000): 24.

${ }^{7}$ Scottish Human Rights Commission, Getting it Right? Human Rights in Scotland, (October 2012), page 10, available at http://www.scottishhumanrights.com/application/resources/documents/SNAP/GettingitRightAn OverviewofHumanRightsinScotland2012.pdf (accessed on 4 July 2016).

${ }^{8}$ Ibid., paragraph 5.1. 
${ }^{9}$ Lawrence O. Gostin and Lance Gable, 'The Human Rights of Persons with Mental Disabilities: A Global Perspective on the Application of Human Rights Principles to Mental Health', Maryland Law Review 63 (2004): 44.

${ }^{10}$ Rosemary Kayess and Philip French, 'Out of Darkness into Light? Introducing the Convention on the Rights of Persons with Disabilities', Human Rights Law Review 8, no. 1 (2008): 14-15.

${ }^{11}$ United Nations General Assembly, Declaration on the Rights of Mentally Retarded Persons, Resolution 2856 (XXVI), 20 December 1971, UN Doc. A/RES/26/2856.

${ }^{12}$ Samantha Maingay et al, 'Mental Health and Human Rights: The MI Principles - Turning Rhetoric into Action', International Review of Psychiatry 14 (2002): 19; Rosenthal and Rubenstein, 'International Human Rights Advocacy under the 'Principles for the Protection of Persons with Mental Illness', 259 and 267; Caroline Gendreau, 'The Rights of Psychiatric Patients in the Light of the Principles Announced by the United Nations: A Recognition of the Right to Consent to Treatment?', International Journal of Law and Psychiatry 20, no. 2 (1997): 268.

${ }^{13}$ Harding, 'Human Rights Law in the Field of Mental Health: A Critical Review', 24.

${ }^{14}$ Winterwerp v Netherlands (1979) ECHR 4.

${ }^{15}$ Winterwerp v Netherlands (1979) ECHR 4; Herczegfalvy v Austria (1992) ECHR 83; Aerts v Belgium (Art 5) (2000) 29 EHRR 50; HL v UK (Art 5) (2004) ECHR 471; Shtukaturov v Russia (Art 5) (2008) ECHR 223; Stanev v Bulgaria (Arts 5 and 8) (2012) ECHR 46; DD $v$ Lithuania (Arts 3, 5 and 8) (2012) ECHR 254; X v Finland (Arts 5 and 8) (2012) ECHR 1371; MH v UK (Art 5) (2008) ECHR 181; Stankov v Bulgaria (Art 5) (Application no. 25820/07, 17 March 2015).

${ }^{16}$ Dybeku v Albania (Art 3) (2007) ECHR 1109; Stanev v Bulgaria (Art 3) (2012) ECHR 46; MS v UK (Art 3) (2012) ECHR 804

${ }^{17}$ Herczegfalvy v Austria (Art 3) (1992) ECHR 83; Keenan v UK (Arts 2 and 3) (2001) ECHR 242; Stanev v Bulgaria (Art 3) (2012) ECHR 46. 
${ }^{18}$ DD v Lithuania (2012) ECHR 254; Shtukaturov v Russia (Art 8) (2008) ECHR 223; Stanev v Bulgaria (Art 8) (2012) ECHR 46; X v Finland (Arts 5 and 8) (2012) ECHR 1371; Ivinovic v Croatia (Application no. 13006/13, 18 September 2014); Lashin v Russia (Art 8) (2013) ECHR 63; Kocherov \& Sergeyov v Russia (Art 8) (Application no. 16899/13, 29 March 2016).

${ }^{19}$ Committee on Economic, Social and Cultural Rights, General Comment No. 14: The Right to the Highest Attainable Standard of Health (Art. 12 of the International Covenant on Economic, Social and Cultural Rights), 11 August 2000, UN Doc. E/C.12/2000/4, paragraph 8.

${ }^{20}$ Ibid., paragraph 4.

${ }^{21}$ Ibid., paragraph 11.

${ }^{22}$ Commission on Human Rights, The Right of Everyone to the Enjoyment of the Highest Attainable Standard of Physical and Mental Health - Report of the Special Rapporteur, Paul Hunt, submitted in accordance with Commission resolution 2002/31, 13 February 2003, UN Doc. E/CN.4/2003/58, paragraph 39.

${ }^{23}$ Paul Hunt and Judith Mesquita 'Mental Disabilities and the Human Right to the Highest Attainable Standard of Health’, Human Rights Quarterly 28 (2006): 333.

${ }^{24}$ Commission on Human Rights, Report of the Special Rapporteur on the Right of Everyone to the Enjoyment of the Highest Attainable Standard of Physical and Mental Health, Paul Hunt, 11 February 2005, UN Doc. E/CN.4/2005/51, paragraph 22. See also, again, WHO, Mental Health: strengthening our response, Factsheet, updated April 2016, available at http://www.who.int/mediacentre/factsheets/fs220/en/ (accessed 10 June 2016).

${ }^{25}$ Commission on Human Rights, Report of the Special Rapporteur on the Right of Everyone to the Enjoyment of the Highest Attainable Standard of Physical and Mental Health, Paul Hunt, 11 February 2005, UN Doc. E/CN.4/2005/51, paragraph 43.

${ }^{26}$ United Nations Human Rights Council, Report of the Special Rapporteur on the right of everyone to the enjoyment of the highest attainable standard of physical and mental health, Dainius Pūras, UN Doc. A/HRC/29/33, 2 April 2015, paragraphs 76-7. 
${ }^{27}$ Ibid., paragraphs 80-1.

${ }^{28}$ Ibid., paragraphs 79 and 81-84.

${ }^{29}$ See Sascha Mira Callaghan \& Christopher Ryan, 'Is There a Future for Involuntary Treatment in Rights-based Mental Health Law?', Psychiatry, Psychology and Law 21, no. 5 (2014): 748; Bernadette McSherry, 'Mental Health and Human Rights: The Role of the Law in Developing a Right to Enjoy the Highest Attainable Standard of Mental Health in Australia’, Faculty of Law, Monash University Research Paper No 2009/31, accessed at http://papers.ssrn.com/sol3/papers.cfm?abstract_id=1599383\#\# (accessed 4 July 2016).

${ }^{30}$ Scottish Government, New Directions - Report on the Review of the Mental Health (Scotland) Act 1984, January 2001, SE/2001/56; Scottish Law Commission, Report on Incapable Adults, September 1995, (Scot Law Com No 151), Cm 2962.

${ }^{31} 2003$ Act, section 1(4).

322000 Act, section 1(3).

${ }^{33}$ Jennifer Fischer, 'A Comparative Look at the Right to Refuse Treatment for Involuntarily Hospitalised Persons with Mental Illness', Hastings International and Comparative Law Review 89 (Winter) (2006): 175.

${ }^{34}$ Scottish Human Rights Commission, Getting it Right? Human Rights in Scotland, (2012) pages 68, 78 and 194.

352003 Act, sections 1(3)(a), (b) and (f); 2000 Act, sections 1(2) and 1(4)(a)-(d).

${ }^{36} 2000$ Act, section 1(5).

${ }^{37}$ Scottish Human Rights Commission, Getting it Right? Human Rights in Scotland, page 69.

${ }^{38}$ Ibid., pages 102-03.

${ }^{39}$ Mental Welfare Commission for Scotland, Visit and Monitoring Report - Intensive psychiatric care in Scotland 2015, (March 2016), available at 
http://www.mwcscot.org.uk/media/315618/intensive_psychiatric_case_in_scotland_report _final.pdf (accessed 23 August 2016).

${ }^{40}$ Convention on the Rights of Persons with Disabilities, adopted 13 December 2006, GA Res 61/106, UN Doc. A/Res/61/106 (entered into force 3 May 2008).

${ }^{41}$ Peter Bartlett, 'Implementing a paradigm shift: implementing the Convention on the Rights of Persons with Disabilities in the context of mental disability law' in Torture in healthcare settings: reflections on the Special Rapporteur on Torture's 2013 Thematic Report (Centre for Human Rights and Humanitarian Law, American University Washington College of Law, 2013).

${ }^{42}$ Annegret Kampf, 'Involuntary Treatment Decisions: Using Negotiated Silence to Facilitate Change?' in Bernadette McSherry and Penelope Weller (eds), Rethinking Rights-Based Mental Health Laws (Oxford: Hart Publishing, 2010) 129-150, 133.

${ }^{43}$ CRPD, Article 1.

${ }^{44}$ Disabled Peoples' International, Position Paper Regarding a New International Human Rights Convention for Disabled People, 25 February 2003, available at http://www.un.org/esa/socdev/enable/rights/contrib-dpi.htm (accessed 4 July 2016).

${ }^{45}$ Meredith Raley, 'The Drafting of the Convention on the Rights of Persons with Disabilities: The Creation of a Novel Mechanism', International Journal of Human Rights 20, no. 1 (2016): 138.

${ }^{46}$ Gauthier de Beco, United Nations Human Rights Office of the High Commissioner, Study on the Implementation of Article 33 of the UN Convention on the Rights of Persons with Disabilities in Europe, (UNHCHR, Europe Regional Office), page 10, (no date), accessed at http://europe.ohchr.org/Documents/Publications/Art 33 CRPD study.pdf (accessed 4 July 2016).

${ }^{47}$ Mental Disability Advocacy Center, Building the Architecture for Change: Guidelines on Article 33 of the UN Convention on the Rights of Persons with Disabilities, (Budapest: MDAC, 2011), available at http://mdac.org/sites/mdac.org/files/Article_33_EN.pdf (accessed 4 July 2016). 
${ }^{48}$ CRPD, Article 33(1).

${ }^{49}$ CRPD, Article 33(2).

${ }^{50}$ United Nations General Assembly, National Institutions for the Promotion and Protection of Human Rights, 20 December 1993, UN Doc. A/RES/48/134.

${ }^{51}$ CRPD, Article 33(3).

${ }^{52}$ de Beco, Study on the Implementation of Article 33 of the UN Convention on the Rights of Persons with Disabilities in Europe, page 8.

${ }^{53}$ CRPD, Article 25(a)

${ }^{54}$ CRPD, Article 25(b)

${ }^{55}$ CRPD, Article 25(d)

${ }^{56}$ United Nations, Promoting the rights of persons with mental and intellectual disabilities, Item 5 (c) of the provisional agenda. Matters related to the implementation of the Convention (round table 2) Conference of States Parties to the Convention on the Rights of Persons with Disabilities, Ninth session New York, 14-16 June 2016. Available at http://www.un.org/disabilities/documents/COP/9/RT2/CRPD_CSP_2016_3-1603538E.pdf (accessed 1 September 2016).

${ }^{57}$ McSherry, 'Mental Health and Human Rights: The Role of the Law in Developing a Right to Enjoy the Highest Attainable Standard of Mental Health in Australia', available at http://papers.ssrn.com/sol3/papers.cfm?abstract_id=1599383\#\#

${ }^{58}$ Bernadette McSherry and Kay Wilson, 'The Concept of Capacity in Australian Mental Health Law Reform: Going in the Wrong Direction?', International Journal of Law and Psychiatry 40 (2015): 60.

${ }^{59}$ Piers Gooding, 'Supported Decision-Making - A Rights-Based Disability Concept and its Implications for Mental Health Law’, Psychiatry, Psychology and Law 20, no. 3 (2013): 439. 
${ }^{60}$ Committee on the Rights of Persons with Disabilities, General Comment No.1 Article 12: Equal Recognition Before the Law, 19 May 2014, UN Doc. CRPD/C/GC/1, paragraph 13.

${ }^{61}$ Ibid., paragraph 17.

${ }^{62}$ See for example: Eilionóir Flynn and Anna Arstein-Kerslake, ‘The Support Model of Legal Capacity: Fact, Fiction, or Fantasy?’, Berkeley Journal of International Law 32 (2014): 134-153; Amita Dhanda, 'Legal Capacity in the Disability Rights Convention: Stranglehold of the Past or Lodestar for the Future?', Syracuse Journal of International Law and Commerce 34 (Spring) (2007): 429-162; Katrine Del Villar, 'Should Supported Decision-Making Replace Substituted Decision-Making? The Convention on the Rights of Persons with Disabilities and Coercive Treatment under Queensland's Mental Health Act 2000', Laws 4 (2015): 173-200; Piers Gooding, 'Navigating the 'Flashing Amber Lights' of the Right to Legal Capacity in the United Nations Convention on the Rights of Persons with Disabilities: Responding to Major Concerns’, Human Rights Law Review 15 (2015): 45-71; Anna Arstein-Kerslake and Eilionóir Flynn, ‘The General Comment on Article 12 of the Convention on the Rights of Persons with Disabilities: A Roadmap for Equality before the Law', International Journal of Human Rights (2015): 1-20.

${ }^{63}$ Tina Minkowitz, 'The United Nations Convention on the Rights of Persons with Disabilities and the Right to be Free from Nonconsensual Psychiatric Interventions', Syracuse Journal of International Law and Commerce 34 (2007): 408.

${ }^{64}$ See Minkowitz, Ibid.; Flynn and Arstein-Kerslake, 'The Support Model of Legal Capacity: Fact, Fiction, or Fantasy?’, 136-7; Dhanda, 'Legal Capacity in the Disability Rights Convention: Stranglehold of the Past or Lodestar for the Future?', 457.

${ }^{65}$ Kayess and French, 'Out of Darkness into Light? Introducing the Convention on the Rights of Persons with Disabilities', 33.

${ }^{66}$ Peter Bartlett, 'A Mental Disorder of a Kind or Degree Warranting Confinement: Examining Justifications for Psychiatric Detention', The International Journal of Human Rights 16, no. 6 (2012): 834.

${ }^{67}$ Rosenthal and Rubenstein, 'International Human Rights Advocacy under the 'Principles for the Protection of Persons with Mental Illness’', 261. 
${ }^{68}$ Bartlett 'A Mental Disorder of a Kind or Degree Warranting Confinement: Examining Justifications for Psychiatric Detention', 834 discusses 'impairment at the core of the mental disability’. See also Eilionóir Flynn and Anna Arstein-Kerslake, 'Legislating Personhood: Realising the Right to Support in Exercising Legal Capacity’, International Journal of the Law in Context 10, no. 1 (2014): 98-100.

${ }^{69}$ Scotland Act 1998, sections 35 and 58.

${ }^{70}$ It should be noted that Scotland has a system of substituted decision-making as defined and 'outlawed' by GC1. This article considers the application of the Article 12 support paradigm within the confines of the Scottish system as it currently exists.

${ }^{71}$ McSherry, 'Mental Health and Human Rights: The Role of the Law in Developing a Right to Enjoy the Highest Attainable Standard of Mental Health in Australia', available at http://papers.ssrn.com/sol3/papers.cfm?abstract_id=1599383\#\#

${ }^{72}$ Eunna Lee and Ditte Johanne Horndrup, 'The Right to Health: An Interview with Professor Paul Hunt', Essex Human Rights Review 2, no. 1 (2005): 57.

${ }^{73}$ Committee on the Rights of Persons with Disabilities, General Comment No.1 Article 12, paragraph 17.

${ }^{74}$ Financial powers of attorney do not necessarily require the grantor to lack capacity in order to become operational.

${ }^{75}$ Committee on the Rights of Persons with Disabilities, General Comment No.1 Article 12, paragraph 17.

${ }^{76}$ The Essex Autonomy Project, Three Jurisdictions Report, Towards Compliance with CRPD Art.12 in Capacity/Incapacity Legislation across the UK, (June 2016), pages 10-14 and 23-33, available at http://autonomy.essex.ac.uk/eap-three-jurisdictions-report (accessed 23 August 2016).

${ }^{77} 2000$ Act, sections 15 and 16. 
${ }^{78}$ Scottish Government, Adults with Incapacity (Scotland) Act 2000 Code of Practice for Continuing and Welfare Attorneys, (Edinburgh: Scottish Government, March 2011), paragraph 2.18.

${ }^{79}$ Jill Stavert, 'The Exercise of Legal Capacity, Supported Decision-Making and Scotland's Mental Health and Incapacity Legislation’, Laws 4 (2015): 305.

${ }^{80} 2003$ Act, section 275(1).

${ }^{81}$ Jacqueline M. Atkinson, 'Advance statements: the view from Scotland', Advances in Psychiatric Treatment 16 (2010): 456.

82 Jacquie Reilly and Jacqueline M. Atkinson, 'The Content of Mental Health Advance Directives: Advance Statements in Scotland', International Journal of Law and Psychiatry 33 (2010): 119.

${ }^{83} 2003$ Act, section 276.

${ }^{84}$ Scottish Government, Limited Review of the Mental Health (Care and Treatment) (Scotland) Act 2003: Report (Edinburgh: Scottish Government, 2009) page 8.

${ }^{85}$ Fiona Morrissey, 'Advance Directives in Mental Health Care: Hearing the Voice of the Mentally Ill’, Medico-Legal Journal of Ireland 16, no. 1 (2010): 23.

${ }^{86} 2003$ Act, section 276A.

${ }^{87} 2003$ Act, section 276B.

${ }^{88} 2003$ Act, section 276C.

${ }^{89} 2003$ Act, section 259(1).

${ }^{90} 2003$ Act, section 259(4).

${ }^{91}$ The Scottish Independent Advocacy Alliance, Principles and Standards for Independent Advocacy, (2008), page 14-16, available at http://www.theadvocacyproject.org.uk/wpcontent/uploads/2012/07/SIAA_Principles_and_Standards.pdf (accessed on 4 July 2016). 
${ }^{92}$ The Scottish Independent Advocacy Alliance, "Advocacy Changed my Life" - Research into the impact of independent advocacy on the lives of people experiencing mental illness, (September 2014), available at http://www.siaa.org.uk/wpcontent/uploads/2014/11/Hanna-report-final-version-31.pdf (accessed on 4 July 2016).

${ }^{93}$ Scottish Government, Independent Advocacy - Guide for Commissioners, (Scottish Government: Edinburgh, 2013), paragraph 7.6, available at http://www.gov.scot/Resource/0044/00441045.pdf (accessed on 4 July 2016).

${ }^{94} 2003$ Act, section 259A.

${ }^{95}$ The Essex Autonomy Project, Three Jurisdictions Report, Towards Compliance with CRPD Art.12 in Capacity/Incapacity Legislation across the UK, page 28.

${ }^{96}$ The Scottish Independent Advocacy Alliance, 'SIAA Response - Consultation on Proposals for a New Mental Health (Scotland) Bill', (March 2014), available at http://www.gov.scot/Resource/0044/00448760.pdf (accessed on 4 July 2016).

${ }^{97}$ Ibid.

${ }^{98}$ This was noted in the Scottish Government's response to the Mental Health Bill Stage 1 Report, see 'Mental Health (Scotland) Bill: Scottish Government Response to Stage 1 Report', (March 2015), page 14-5, available at http://www.scottish.parliament.uk/S4_HealthandSportCommittee/SGDocs/Scottish_Gover nment_response___Mental_Health_(Scotland)_Bill___Stage_1.pdf (accessed on 4 July 2016).

${ }^{99}$ Mental Welfare Commission for Scotland, 'MSPs Briefing - Mental Health (Scotland) Bill stage 1 debate, 12 March 2015’, (March 2015), available at http://www.mwcscot.org.uk/about-us/latest-news/msps-briefing-on-mental-health(scotland)-bill/ (accessed on 4 July 2016).

${ }^{100}$ Scottish Human Rights Commission, Getting it Right? Human Rights in Scotland, page 15.

${ }^{101}$ There is now an Independent Living Fund for Scotland. 
102 The Scottish Independent Advocacy Alliance, A Map of Advocacy across Scotland - 20132014 Edition, (2014), page 2, available at http://www.siaa.org.uk/wpcontent/uploads/2014/10/Advocacy-Map-201314.pdf (accessed on 4 July 2016).

${ }^{103}$ Committee on Economic, Social and Cultural, Concluding obligations on the sixth periodic report of the United Kingdom and Northern Ireland, E/C.12/GBR/CO/6, para 18.

${ }^{104}$ Ibid., para 19.

${ }^{105}$ The Essex Autonomy Project, Three Jurisdictions Report, Towards Compliance with CRPD Art.12 in Capacity/Incapacity Legislation across the UK.

${ }^{106}$ Ibid., Recommendation 1, page 1.

${ }^{107}$ Ibid., pages 10-14 and 23-33.

${ }^{108}$ In the UK's CRPD State report the role of the focal points was described as follows:

'ODI and the devolved government focal points help government policy departments that are responsible for the delivery of Convention rights in their policy areas, to ensure that they are aware of the obligations of the Convention, and consider them as they develop new legislation, policies and programmes.'

Committee on the Rights of Persons with Disabilities, Initial reports of States parties due in 2011, United Kingdom of Great Britain and Northern Ireland (24 November 2011), 3 July 2013, UN Doc. CRPD/C/GBR/1, paragraph 349.

${ }^{109}$ Scottish Government, United Nations Convention on the Rights of Persons with Disabilities The Scottish Government's Draft Delivery Plan 2016-2020, September 2015, available at http://www.gov.scot/Resource/0048/00484854.pdf (accessed 23 August 2016).

${ }^{110}$ CRPD, Article 33(2).

${ }^{111}$ UK Independent Mechanism, Monitoring the Implementation of the UN Convention on the Rights of Persons with Disabilities - The UK Independent Mechanism List of Issues Interim Report, December 2014, page 26, available at https://www.equalityhumanrights.com/sites/default/files/monitoring_the_implementation_ of_the_uncrpd2.pdf (accessed on 23 August 2016). 
${ }^{112}$ Ibid.

${ }^{113}$ Ibid.

${ }^{114}$ Joint Committee on Human Rights, Implementation of the Right of Disabled People to Independent Living, HL Paper 257, (February 2012), page 36, available at http://www.publications.parliament.uk/pa/jt201012/jtselect/jtrights/257/257.pdf (accessed on 23 August 2016).

${ }^{115}$ Scottish Government, 'Mental Health Funding', news release, 12 January, 2016 available at http://news.scotland.gov.uk/News/Mental-health-funding-2139.aspx (accessed 23 August 2016).

${ }^{116}$ Scottish Government, Consultation on The Scottish Law Commission Report on Adults with Incapacity, (Scottish Government: Edinburgh, 2015), available at https://consult.scotland.gov.uk/integration-partnerships/report-on-adults-with-incapacity (accessed on 23 August 2016).

${ }^{117}$ Scottish Government, Mental Health in Scotland - A 10 Year Vision, (Scottish Government: Edinburgh, 2016), available at https://consult.scotland.gov.uk/mental-health-unit/mentalhealth-in-scotland-a-10-year-vision/user_uploads/440179 mental_p2.pdf (accessed on 1 September 2016).

${ }^{118}$ Scottish Association for Mental Health, Talking it Out - Psychological Therapies in Scotland, available at https://www.samh.org.uk/media/465573/talkingitout.pdf (accessed 23 August 2016).

119 The UK, for example, has been criticised by the UN Committee on Economic, Social and Cultural Rights for regarding socio-economic rights as mere values and not incorporating them, so that they are legally enforceable, into domestic laws. See Committee on Economic, Social and Cultural Rights, Consideration of Reports Submitted by States Parties Under Articles 16 and 17 of the Covenant, Concluding Observations (United Kingdom of Great Britain and Northern Ireland), 22 May 2009, UN Doc. E/C.12/GBR/CO/5, paragraph 13.

${ }^{120}$ Eilionóir Flynn in Disabled justice: Access to Justice and the UN Convention on the Rights of Persons with Disabilities (Ashgate, 2015), strongly reinforces the fact that equal and 
non-discriminatory access to the justice system is integral to the achievement of equal rights for persons with disabilities.

${ }^{121}$ McSherry and Wilson, ‘The concept of capacity in Australian Mental Health Law Reform: Going in the Wrong Direction?', 68.

${ }^{122}$ Scottish Human Rights Commission, Getting it Right? Human Rights in Scotland, page 32.

${ }^{123}$ CRPD, Art 4(3).

${ }^{124}$ World Health Organisation, Mental Health Action Plan 2013/2020, 2013, Geneva, see, for example, paragraphs 51, 57 and 62. 